\title{
PENGARUH PENAMBAHAN SURFAKTAN DAN WAKTU TURUN HUJAN SETELAH APLIKASI TERHADAP DAYA KENDALI HERBISIDA GLIFOSAT
}

\section{EFFECT OF SURFACTANT AND TIME OF RAINFALL AFTER APPLICATION ON THE EFFICACY OF GLYPHOSATE HERBICIDE}

\author{
Meylita Mustikawati*, Dad R. J. Sembodo, Purba Sanjaya dan Hidayat Pujisiswanto \\ Jurusan Agroteknologi, Fakultas Pertanian, Universitas Lampung, Lampung, Indonesia \\ Jl. Prof. Soemantri Brodjonegoro, No. 1, Bandar Lampung 32145 \\ *E-mail: mustikameylita@gmail.com
}

\begin{abstract}
The application of glyphosate herbicide was chosen to control weeds because it had a broad spectrum. Rain is one factor that can reduce the effectiveness of glyphosate herbicides while the addition of surfactants in glyphosate herbicide applications can increase the effectiveness. The purpose of this research was to determine the effect of addition of surfactants and the time of rainfall after herbicide application and their interaction with the efficacy of glyphosate herbicide. This research used a split plot design with 14 treatments and 5 replications tested on weeds (Paspalum conjugatum, Setaria plicata, Asystasia gangetica, Praxelis clematidea, Cyperus rotundus, and Cyperus kyllingia). The main plot is without surfactant and surfactant addition of $0.1 \%$ and subplot is time of rainfall after application with the time of rainfall is 0, 1, 2, 3, 4 hours, and no rainfall after application. The datas were analyzed of variance and further tested with the Least Significant Difference test (LSD) level of 5\%. The results showed that the addition of surfactant can increase the efficacy of glyphosate herbicide, and the rain fall time after application can reduce the efficacy of glyphosate herbicide. The addition of surfactant to the application of glyphosate herbicides followed by the rain after application has higher efficacy compared to the herbicide application without surfactants.
\end{abstract}

Keywords: Glyphosate herbicide, rain, surfactant, weeds

\begin{abstract}
ABSTRAK
Aplikasi herbisida glifosat banyak dipilih untuk mengendalikan gulma karena memiliki spektrum pengendalian yang luas. Hujan merupakan salah satu faktor yang dapat menurunkan efektivitas herbisida glifosat sedangkan penambahan surfaktan dalam aplikasi herbisida glifosat dapat meningkatkan efektivitas herbisida tersebut. Tujuan penelitian untuk mengetahui pengaruh penambahan surfaktan dan waktu turun hujan setelah aplikasi serta interaksinya terhadap daya kendali herbisida glifosat. Penelitian menggunakan rancangan petak terbagi dengan 14 perlakuan dengan 5 ulangan yang diujikan pada gulma Paspalum conjugatum, Setaria plicata, Asystasia gangetica, Praxelis clematidea, Cyperus rotundus, dan Cyperus kyllingia. Petak utama yaitu tanpa penambahan surfaktan dan penambahan surfaktan $0,1 \%$ sedang anak petak yaitu waktu turun hujan setelah aplikasi dengan
\end{abstract}


waktu turun hujan $0,1,2,3,4$, dan tanpa hujan setelah aplikasi. Data dianalisis ragam dan diuji lanjut dengan uji Beda Nyata Terkecil (BNT) taraf 5\%. Hasil penelitian menunjukkan bahwa penambahan surfaktan dapat meningkatkan daya kendali herbisida glifosat, dan waktu turun hujan setelah aplikasi dapat menurunkan daya kendali herbisida glifosat. Penambahan surfaktan pada aplikasi herbisida glifosat yang diikuti hujan setelah aplikasi memiliki daya kendali yang lebih tinggi dibandingkan dengan aplikasi herbisida tanpa surfaktan.

Kata kunci: Gulma, herbisida glifosat, hujan, surfaktan

\section{PENDAHULUAN}

Hujan sangat berpengaruh terhadap produksi hasil pertanian, setiap peningkatan curah hujan $1 \mathrm{~mm} /$ tahun di Sumatera Utara dari tahun 2000-2016 dapat meningkatkan produksi tanaman jagung sebesar 172,01 ton (Tampubolon dkk., 2017). Selain itu, curah hujan sangat berpengaruh terhadap peningkatan pertumbuhan gulma (Shiddieq dkk., 2018), semakin tinggi curah hujan maka semakin banyak gulma yang akan tumbuh.

Keberadaan gulma di areal budidaya akan menjadi pesaing bagi tanaman utama dalam memanfaatkan nutrisi, cahaya, $\mathrm{CO}_{2}, \mathrm{O}_{2}$, dan air, serta secara tidak langsung dapat meracuni tanaman utama melalui alelopati. Kompetisi yang terjadi dapat menurunkan hasil hingga 100\% atau tanaman mengalami puso pada kebanyakan jenis tanaman budidaya (Sembodo, 2010). Sehingga perlu dilakukan pengendalian gulma. Pengendalian gulma dapat dilakukan dengan berbagai cara, salah satunya secara kimiawi. Pengendalian secarakimiawimerupakan metode yang banyak digunakan karena pengaplikasiannya mudah dan menunjukkan efek yang relatif cepat.

Herbisida glifosat merupakan herbisida yang banyak digunakan karena memiliki spektrum pengendalian yang luas. Herbisida glifosat diaplikasikan pada tajuk daun sehingga memiliki kemungkinan yang besar untuk tercuci oleh air hujan. Sehingga dibutuhkan penambahan surfaktan untuk meningkatkan kemampuan herbisida tersebut masuk kedalam jaringan gulma (Gitsopoulus dkk., 2014).

Surfaktan adalah jenis adjuvant yang dirancang untuk meningkatkan pembasah, pengemulsi, pendispersi, penyebaran, atau sifat lain dari cairan yang bertujuan untuk meningkatkan efektivitas herbisida (Miller dan Westra, 1998). Surfaktan diformulasikan dengan konsentrasi kritis misel (agregasi ion-ion surfaktan) yaitu $0,1 \%$ hingga $0,5 \%$ (Cobb dan Reade, 2010). Selain itu, surfaktan yang mengandung minyak dapat berinteraksi dengan kutikula, membantu bahan aktif masuk ke dalam sel tumbuhan, sehingga dapat meningkatkan aktivitas herbisida tersebut (Hall, 2014). Oleh karena itu, perlu diketahui pengaruh surfaktan dan waktu turun hujan setelah aplikasi serta interaksinya terhadap daya kendali herbisida glifosat.

\section{BAHAN DAN METODE}

Penelitian dilaksanakan pada bulan November 2018 hingga Januari 2019 di rumah plastik Kebun Penelitian Desa Hajimena Kecamatan Natar Lampung 
Selatan. Alat yang digunakan adalah knapsack sprayer, sprinkler tipe Jet-120, pipa, wadah berdiameter $20 \mathrm{~cm}$, gelas ukur, alat tulis, gelas plastik, oven, timbangan digital, pipet tetes, rubber bulb, dan stopwatch. Bahan yang digunakan adalah herbisida berbahan aktif glifosat dengan merek dagang Roundup biosorp $486 \mathrm{SL}$, surfaktan merek KAO adjuvant A134 (water bassed), air, tanah, kantung kertas, pupuk kandang, dan bibit gulma (Paspalum conjugatum, Setaria plicata, Praxelis clematidea, Asystasia gangetica, Cyperus rotundus, dan Cyperus kyllingia).

Penelitian disusun dalam rancangan petak terbagi (split-plot design), dengan petak utama yaitu penambahan surfaktan terdiri dari dengan penambahan surfaktan dan tanpa penambahan surfaktan, dan anak petak yaitu waktu turun hujan setelah aplikasi yang terdiri dari waktu turun hujan 0, 1, 2, 3, 4 jam dan tidak hujan setelah aplikasi. Pengolahan data diuji dengan analisis ragam, homogenitas ragam diuji dengan uji Bartlet, aditivitas data diuji dengan uji Tukey, dan perbedaan nilai tengah diuji denganuji BNT pada taraf $5 \%$.

Setiap perlakuan diujikan pada enam jenis gulma yaitu golongan rumput (Paspalum conjugatum dan Setaria plicata), golongan daun lebar (Asystasia gangetica dan Praxelis clematidea), dan golongan teki (Cyperus rotundus dan Cyperus kyllingia). Gulma ditanam dalam pot berisi media tanah dan pupuk kandang dengan perbandingan 2:1, gulma diambil dari sekitar lahan penelitian yang memiliki 2-3 helai daun. Dilakukan penyiraman dan pemeliharaan hingga gulma tumbuh normal.

Gulma diaplikasikan herbisida glifosat pada
19 hari setelah tanam. Aplikasi dilakukan pada petakan berukuran 1,5 m x $6 \mathrm{~m}$ untuk setiap petak (petak dengan penambahan surfaktan dan tanpa penambahan surfaktan). Menggunakan herbisida glifosat (Roundup biosorp $486 \mathrm{SL}$ ) dengan dosis bahan aktif $1215 \mathrm{~g} / \mathrm{ha}$ dan surfaktan KAO adjuvant A-134 sebesar 0,1\%. Dengan volume semprot knapsack sprayer yang digunakan adalah $500 \mathrm{ml} / 9 \mathrm{~m}^{2}$ atau 5561/ha.

Simulasi hujan dilakukan setelah aplikasi herbisida glifosat, dilakukan selama 1 jam dengan intensitas 36 mm/jam (Pers. (1)). Dimulai dari waktu turun hujan tercepat yaitu $0,1,2,3$, dan 4 jam setelah aplikasi(JSA). Intensitascurah hujan diperoleh dari kalibrasi sprinkler selama 15 menit(Pers. (2)) dengan penempatan sprinkler dan penakar curah hujan seperti Gambar 1.

$$
\begin{aligned}
\text { Intensitas hujan }= & \frac{\text { Tinggi hujan }(\mathrm{mm})}{\text { Waktu turun hujan }} \\
& =\frac{8,98 \mathrm{~mm}}{15 \mathrm{menit}} \\
& =0,60 \mathrm{~mm} / \mathrm{menit} \\
& =36 \mathrm{~mm} / \mathrm{jam}
\end{aligned}
$$

Dengan tinggi hujan diperoleh melalui rumus :

$$
\begin{aligned}
\text { Tinggi hujan } & =\frac{\text { Volume air hujan }(\mathrm{ml})}{\text { Luas penampang }} \\
& =\frac{282 \mathrm{ml}}{314 \mathrm{~cm}^{2}}=8,98 \mathrm{~mm}
\end{aligned}
$$

Pengamatan dilakukan pada 3, 6, 9, 12, dan 15 hari setelah aplikasi (HSA) dengan variabel yang diamati yaitu persentase keracunan. Pada hari terakhir pengamatan dilakukan pengamatan bobot kering gulma dengan memanem tajuk gulma dan melakukan pengeringan dengan oven bersuhu $80^{\circ}$ selama 48 jam. Selanjutnya, data bobot kering yang diperoleh digunakan untuk mengetahui persentase kerusakannya. 


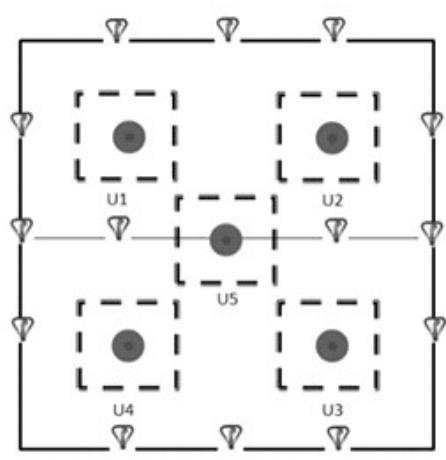

$$
\text { Keterangan : } \begin{aligned}
\odot & =\text { penakar curah hujan } \\
\nabla & =\text { sprinkler } \\
- & =\text { pipa air } \\
\vdots_{-}-{ }_{1} & =\text { tempat pot gulma }
\end{aligned}
$$

Gambar 1. Tata letak sprinkler

\section{HASIL DAN PEMBAHASAN}

\section{Daya kendali herbisida glifosat pada}

gulma total. Pengaruh penambahan surfaktan pada aplikasi herbisida glifosat dan waktu turun hujan setelah aplikasi dapat dilihat dari persentase keracunan gulma dan bobot kering gulma serta persentase kerusakannya.

Persentase keracunan gulma total diperoleh dari rata-rata persentase keracunan enam gulma yang diaplikasikan herbisida glifosat yaitu Paspalum conjugatum, Setaria plicata, Asystasia gangetica, Praxelis clematidea, Cyperus rotundus, dan Cyperus kyllingia. Pengamatan 15 HSA menunjukkan bahwa hujan dapat menurunkan persentase keracunan gulma total sebesar 44-79\% pada aplikasi herbisida glifosat tanpa penambahan surfaktan. Pada aplikasi herbisida glifosat dengan penambahan surfaktan, hujan dapat menurunkan persentase keracunan gulma total sebesar $32-61 \%$ (Gambar 2).

Penambahan surfaktan pada aplikasi herbisida glifosat dapat meningkatkan persentase keracunan gulma total kecuali pada aplikasi herbisida glifosat yang tidak diikuti hujan setelah aplikasi. Selisih persentase keracunan antara aplikasi herbisida glifosat dengan penambahan surfaktan dan tanpa surfaktan pada aplikasi herbisida glifosat yang diikuti hujan $0,1,2,3$, dan 4 JSA secara berurut adalah 15, 19, 18, 8 dan 8\%. Singh dkk. (2009) menyatakan bahwa penambahan adjuvant dapat membantu meningkatkan ketahanan herbisida glifosat agar tidak tercuci oleh hujan, sehingga persentase keracunannya akan lebih tinggi dibandingkan dengan tanpa surfaktan.

Aplikasi herbisida glifosat lebih efektif dengan tanpa penambahan surfaktan apabila tidak diikuti terjadinya hujan setelah aplikasi. Berdasarkan penelitian yang dilakukan oleh Riechers dkk. (1995) penambahan surfaktan jenis nonionik alliol dan octoxynol tidak efektif diformulasikan dengan herbisida glifosat. Hal tersebut dapat terjadi karena penambahan surfaktan pada formulasi herbisida dan larutan semprot memiliki kemungkinan tidak berpengaruh terhadap fitotoksisitas herbisida, surfaktan dapat meningkatkan atau justru menghambat fitotoksisitas herbisida (Anderson, 1982). Hujan yang turun 0-4 JSA dapat mencuci herbisida yang menempel pada permukaan gulma, sehingga terjadi penurunan tingkatkeracunan gulmajika dibandingkan dengan tanpa adanya hujan setelah 


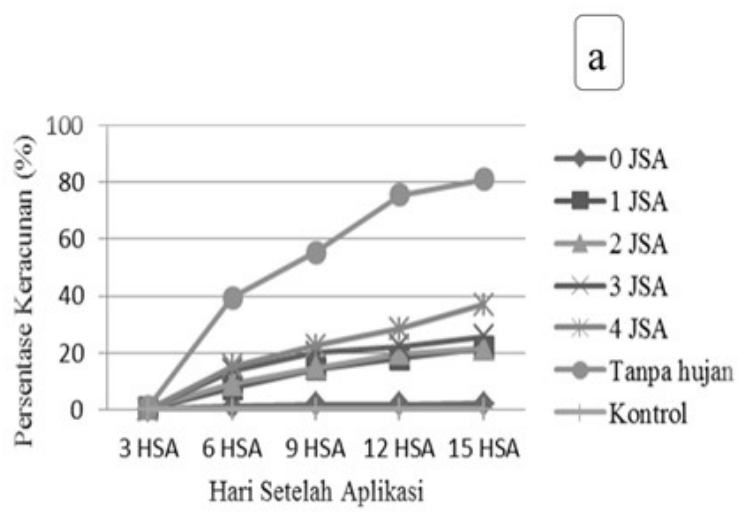

Keterangan :

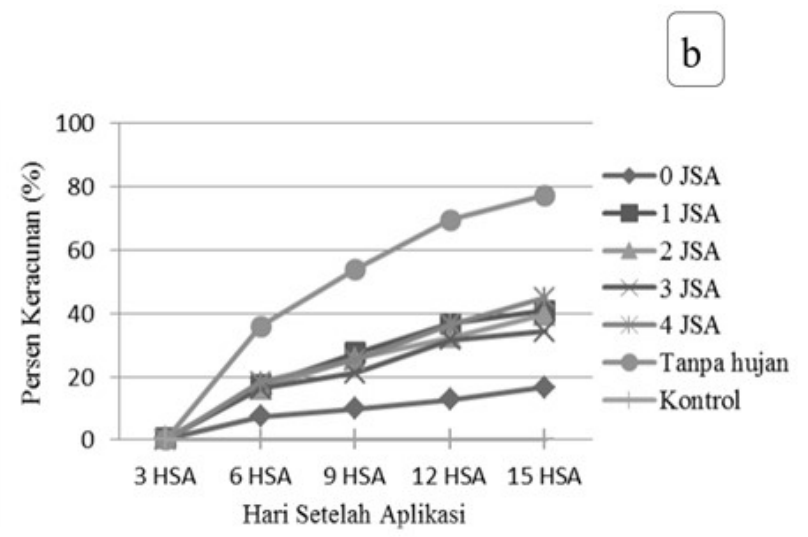

JSA $=$ Jam Setelah Aplikasi $;$ HSA $=$ Hari Setelah Aplikasi

Gambar 2. Persentase keracunan gulma total: a) tanpa penambahan surfaktan, b) penambahan surfaktan

aplikasi. Hujan yang terjadi segera setelah aplikasi menghasilkan bobot kering gulma total tertinggi, karena herbisida yang tercuci lebih banyak. Sedangkan aplikasi herbisida glifosat yang tidak diikuti adanya hujan setelah aplikasi memiliki bobot kering gulma total terendah (Tabel 1). Semakin lama rentang waktu dari aplikasi herbisida dengan terjadinya hujan setelah aplikasi akan memiliki bobot kering yang semakin rendah(Tabel 1).

Penambahan surfaktan dapat mengurangi tingkat kehilangan herbisida pada permukaan gulma yang tercuci oleh hujan. Penambahan surfaktan menyebabkan bobot kering gulma total menjadi lebih rendah dibandingkan dengan tanpa penambahan surfaktan.

Besarnya bobot kering gulma total akan mempengaruhi besarnya persentase kerusakan gulma tersebut. Persentase kerusakan gulma total pada aplikasi herbisida glifosat yang diikuti hujan setelah aplikasi akan lebih rendah jika dibandingkan dengan tanpa diikuti hujan setelah aplikasi. Persentase kerusakan gulma total meningkat dengan adanya penambahan surfaktan, kecuali pada aplikasi herbisida glifosat yang tidak diikuti adanya hujan setelah aplikasi.

Penambahan surfaktan dapat menurunkan bobot kering dan meningkatkan persentase kerusakan gulma total, sedangkan waktu turun hujan setelah aplikasi dapat meningkatkan bobot kering dan menurunkan persentase kerusakan gulma total. Hal tersebut sejalan dengan penelitian yang dilakukan oleh Girsang (2005), yang menyatakan bahwa hujan 2 JSA tidak mengurangi efektivitas herbisida isopropilamina glifosat. Pemberian surfaktan mampu meningkatan persentase kerusakan gulma total sehingga pertumbuhan gulma menjadi tertekan. Menurut Sulistyono dkk. (1999) herbisida glifosat yang diaplikasikan dengan penambahan surfaktan $0,2 \%$ dapat mengendalikan gulma lebih baik dibandingkan dengan tanpa penambahan surfaktan.

\section{Daya kendali herbisida glifosat pada} gulma rumput. Gulma golongan rumput yang digunakan sebagai gulma uji yaitu gulma Paspalum conjugatum dan Setaria plicata. 
Tabel 1. Pengaruh penambahan surfaktan dan waktu turun hujan setelah aplikasi terhadap bobot kering gulma total, gulma rumput, gulma daun lebar, dan gulma teki

\begin{tabular}{|c|c|c|c|c|c|c|c|c|}
\hline \multirow{3}{*}{$\begin{array}{c}\text { Perlakuan } \\
\text { Waktu Turun } \\
\text { Hujan (Jam } \\
\text { Setelah Aplikasi) }\end{array}$} & \multicolumn{8}{|c|}{ Bobot Kering $(\mathrm{g})$} \\
\hline & \multicolumn{2}{|c|}{ Gulma Total } & \multicolumn{2}{|c|}{ Gulma Rumput } & \multicolumn{2}{|c|}{ Gulma Daun Lebar } & \multicolumn{2}{|c|}{ Gulma Teki } \\
\hline & $\begin{array}{c}\text { Tanpa } \\
\text { Surfaktan }\end{array}$ & $\begin{array}{l}\text { Dengan } \\
\text { Surfaktan }\end{array}$ & $\begin{array}{c}\text { Tanpa } \\
\text { Surfaktan }\end{array}$ & $\begin{array}{l}\text { Dengan } \\
\text { Surfaktan }\end{array}$ & $\begin{array}{c}\text { Tanpa } \\
\text { Surfaktan }\end{array}$ & $\begin{array}{l}\text { Dengan } \\
\text { Surfaktan }\end{array}$ & $\begin{array}{c}\text { Tanpa } \\
\text { Surfaktan }\end{array}$ & $\begin{array}{c}\text { Dengan } \\
\text { Surfaktan }\end{array}$ \\
\hline Kontrol & $\begin{array}{c}1,44 \mathrm{a} \\
\mathrm{p}\end{array}$ & $\begin{array}{c}1,43 \mathrm{a} \\
\mathrm{p}\end{array}$ & $\begin{array}{c}1,79 \mathrm{a} \\
\mathrm{q}\end{array}$ & $\begin{array}{c}1,98 \mathrm{a} \\
\mathrm{p}\end{array}$ & $\begin{array}{c}1,41 \mathrm{a} \\
\mathrm{p}\end{array}$ & $\begin{array}{c}1,37 \mathrm{a} \\
\mathrm{q}\end{array}$ & $\begin{array}{c}1,13 \mathrm{a} \\
\mathrm{p}\end{array}$ & $\begin{array}{c}0,94 \text { a } \\
q\end{array}$ \\
\hline 0 & $\begin{array}{c}0,86 \mathrm{~b} \\
\mathrm{p}\end{array}$ & $\begin{array}{c}0,67 b \\
q\end{array}$ & $\begin{array}{c}0,98 \mathrm{~b} \\
\mathrm{p}\end{array}$ & $\begin{array}{c}0,44 b \\
q\end{array}$ & $\begin{array}{c}1,09 \mathrm{~b} \\
\mathrm{p}\end{array}$ & $\begin{array}{c}1,16 b \\
p\end{array}$ & $\begin{array}{c}0,50 \mathrm{~b} \\
\mathrm{p}\end{array}$ & $\begin{array}{c}0,40 \mathrm{~b} \\
\mathrm{q}\end{array}$ \\
\hline 1 & $\begin{array}{c}0,51 \mathrm{c} \\
\mathrm{p}\end{array}$ & $\begin{array}{c}0,37 \mathrm{c} \\
\mathrm{q}\end{array}$ & $\begin{array}{c}0,48 \mathrm{~d} \\
\mathrm{p}\end{array}$ & $\begin{array}{c}0,18 \mathrm{c} \\
\mathrm{q}\end{array}$ & $\begin{array}{c}0,62 \mathrm{c} \\
\mathrm{p}\end{array}$ & $\begin{array}{c}0,56 \mathrm{c} \\
\mathrm{p}\end{array}$ & $\begin{array}{c}0,42 \mathrm{c} \\
\mathrm{p}\end{array}$ & $\begin{array}{c}0,39 b \\
q\end{array}$ \\
\hline 2 & $\begin{array}{c}0,56 \mathrm{c} \\
\mathrm{p}\end{array}$ & $\begin{array}{c}0,40 \mathrm{c} \\
\mathrm{q}\end{array}$ & $\begin{array}{c}0,63 \mathrm{c} \\
\mathrm{p}\end{array}$ & $\begin{array}{c}0,24 \mathrm{c} \\
\mathrm{q}\end{array}$ & $\begin{array}{c}0,65 \mathrm{c} \\
\mathrm{p}\end{array}$ & $\begin{array}{c}0,56 \mathrm{c} \\
\mathrm{q}\end{array}$ & $\begin{array}{c}0,41 \mathrm{c} \\
\mathrm{p}\end{array}$ & $\begin{array}{c}0,39 \mathrm{~b} \\
\mathrm{p}\end{array}$ \\
\hline 3 & $\begin{array}{c}0,54 \mathrm{c} \\
\mathrm{p}\end{array}$ & $\begin{array}{c}0,36 \mathrm{c} \\
\mathrm{q}\end{array}$ & $\begin{array}{c}0,49 \mathrm{~d} \\
\mathrm{p}\end{array}$ & $\begin{array}{c}0,16 \mathrm{c} \\
\mathrm{q}\end{array}$ & $\begin{array}{c}0,67 \mathrm{c} \\
\mathrm{p}\end{array}$ & $\begin{array}{c}0,55 \mathrm{c} \\
\mathrm{q}\end{array}$ & $\begin{array}{c}0,45 \mathrm{bc} \\
\mathrm{p}\end{array}$ & $\begin{array}{c}0,35 b \\
q\end{array}$ \\
\hline 4 & $\begin{array}{c}0,42 \mathrm{~d} \\
\mathrm{p}\end{array}$ & $\begin{array}{c}0,29 d \\
q\end{array}$ & $\begin{array}{c}0,30 \mathrm{~d} \\
\mathrm{p}\end{array}$ & $\begin{array}{c}0,18 \mathrm{c} \\
\mathrm{q}\end{array}$ & $\begin{array}{c}0,64 \mathrm{c} \\
\mathrm{p}\end{array}$ & $\begin{array}{c}0,40 \mathrm{~d} \\
\mathrm{q}\end{array}$ & $\begin{array}{c}0,33 \mathrm{~d} \\
\mathrm{p}\end{array}$ & $\begin{array}{c}0,29 \mathrm{c} \\
\mathrm{q}\end{array}$ \\
\hline Tanpa hujan & $\begin{array}{c}0,05 \mathrm{e} \\
\mathrm{p}\end{array}$ & $\begin{array}{c}0,05 \mathrm{e} \\
\mathrm{p}\end{array}$ & $\begin{array}{c}0,00 \mathrm{e} \\
\mathrm{p}\end{array}$ & $\begin{array}{c}0,03 \mathrm{~d} \\
\mathrm{p}\end{array}$ & $\begin{array}{c}0,01 \mathrm{~d} \\
\mathrm{p}\end{array}$ & $\begin{array}{c}0,00 \mathrm{e} \\
\mathrm{p}\end{array}$ & $\begin{array}{c}0,14 \mathrm{e} \\
\mathrm{p}\end{array}$ & $\begin{array}{c}0,12 \mathrm{~d} \\
\mathrm{q}\end{array}$ \\
\hline
\end{tabular}

Keterangan : Angka yang diikuti huruf yang sama tidak berbeda nyata dengan uji BNT pada taraf $5 \%$; Huruf a,b,c,d,e merupakan notasi pada kolom yang sama. Huruf $\mathrm{p}, \mathrm{q}$ merupakan notasi pada baris yang sama. BNT bobot kering gulma total petak utama (Penambahan surfaktan) 0,02 dan BNT anak petak (Waktu turun hujan) 0,06. BNT bobot kering gulma rumput petak utama (Penambahan surfaktan) 0,08 dan BNT anak petak (Waktu turun hujan) 0,12. BNT bobot kering gulma daun lebar petak utama (Penambahan surfaktan) 0,08 dan BNT anak petak (Waktu turun hujan) 0,08. BNT bobot kering gulma teki petak utama (Penambahan surfaktan) 0,02 dan BNT anak petak (Waktu turun hujan) 0,05 .

Hujan yang terjadi setelah aplikasi herbisida glifosat tanpa penambahan surfaktan menyebabkan penurunan persentase keracunan gulma rumput sebesar 48-96\% dan 26-51\% pada aplikasi herbisida glifosat dengan penambahan surfaktan pada pengamatan 15 HSA (Gambar 3).

Hujan yang terjadi setelah aplikasi herbisida glifosat dapat menurunkan persentase keracunan gulma rumput jika dibandingkan dengan tanpa adanya hujan setelah aplikasi. Penambahan surfaktan pada aplikasi herbisida glifosat dapat meningkatkan persentase keracunan gulma rumput kecuali pada aplikasi yang tidak diikuti hujan setelah aplikasi. Selisih persentase keracunan antara aplikasi herbisida dengan penambahan surfaktan dan tanpa surfaktan pada hujan yang terjadi $0,1,2,3$, dan 4 JSA secara berurut adalah 33, 33, 32, 22, dan 9\% (Gambar 3).

KAO adjuvant A-134 yang digunakan berasal dari palm kernel oil (Redaksi SI, 2018). Surfaktan yang tergolong kedalam konsentrat minyak tanaman mampu mengurangi tegangan permukaan dan meningkatkan penyerapan herbisida pada daun (Miller dan Westra, 1998). Pada saat terjadi hujan setelah aplikasi herbisida, herbisida yang diaplikasikan dengan penambahan surfaktan dapat meningkatkan penyerapan herbisida oleh daun, sedangkan herbisida yang tidak ditambah surfaktan akan tercuci lebih banyak. Akan tetapi, terlalu banyak surfaktan atau wetting agent dapat meningkatkan kemungkinan tetesan semprot tergelincir dari permukaan gulma (Moenandir, 1990). 

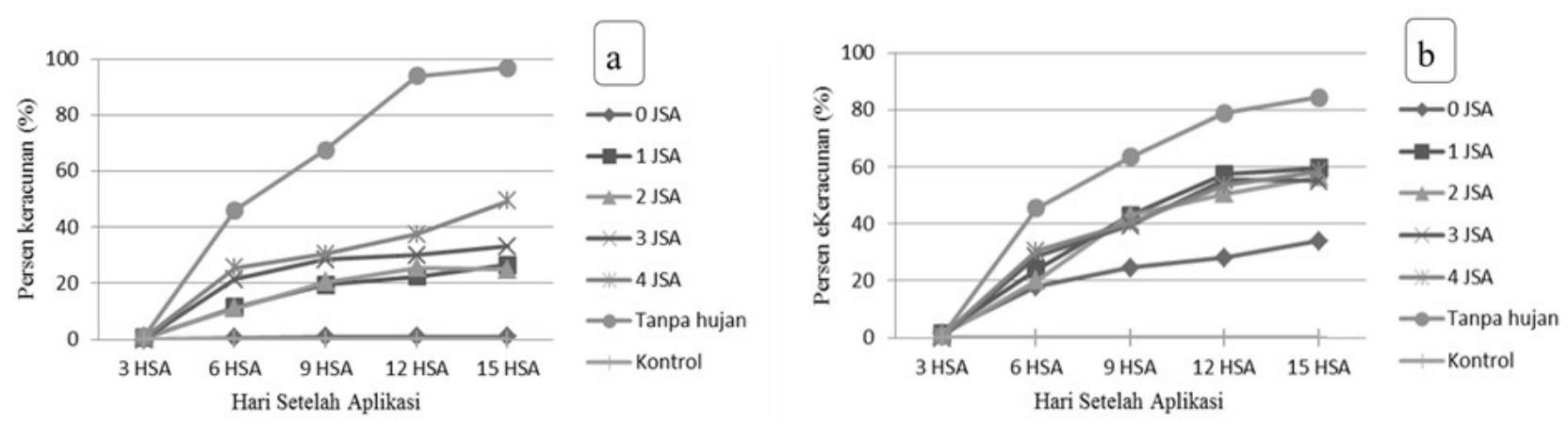

Keterangan :

JSA $=$ Jam Setelah Aplikasi ; HSA $=$ Hari Setelah Aplikasi

Gambar 3. Persentase keracunan gulma rumput: a) tanpa penambahan surfaktan, b) penambahan surfaktan

Hujan yang terjadi setelah aplikasi herbisida glifosat dapat mencuci herbisida yang menempel pada permukaan gulma rumput, sehingga tingkat keracunannya akan lebih rendah dan meningkatkan bobot kering gulma rumput. Semakin lama rentang waktu antara aplikasi herbisida dengan terjadinya hujan maka akan semakin rendah bobot kering yang dihasilkan (Tabel 1). Penambahan surfaktan pada aplikasi herbisida glifosat yang diikuti terjadinya hujan 1-4 JSA menghasilkan bobot kering gulma rumput yang lebih rendah dibandingkan dengan aplikasi tanpa penambahan surfaktan (Tabel 1).

Persentase kerusakan gulma rumput pada aplikasi herbisida glifosat yang diikuti hujan setelah aplikasi akan lebih rendah jika dibandingkan dengan aplikasi yang tidak diikuti hujan setelah aplikasi. Penambahan surfaktan dapat meningkatkan persentase kerusakan gulma rumput. Penambahan surfaktan pada aplikasi herbisida glifosat yang diikuti hujan 0-4 JSA memiliki persentase kerusakan yang lebih tinggi dibandingkan dengan tanpa penambahan surfaktan. Pada semua jenis gulma, hujan deras dapat menyebabkan herbisida yang tercuci lebih banyak, akan tetapi ketahanannya terhadap pencucian oleh hujan dapat ditingkatkan dengan penambahan surfaktan (Hunsche dkk., 2007).

\section{Daya kendali herbisida glifosat pada gulma}

daun lebar. Gulma daun lebar yang digunakan sebagai gulma uji yaitu Asystasia gangetica dan Praxelis clematidea. Tercucinya herbisida yang menempel pada permukaan gulma oleh hujan dapat menurunkan tingkat keracunan gulma daun lebar. Pengamatan 15 HSA menunjukkan bahwa hujan yang terjadi setelah aplikasi herbisida glifosat tanpa penambahan surfaktan dapat menurunkan persentase keracunan gulma daun lebar sebesar 63-95\%, sedangkan pada aplikasi dengan penambahan surfaktan sebesar 51-96\%(Gambar 4).

Persentase keracunan gulma daun lebar pada aplikasi herbisida dengan penambahan surfaktan lebih tinggi dibandingan dengan aplikasi tanpa penambahan surfaktan kecuali pada aplikasi yang tidak diikuti hujan setelah aplikasi, dengan selisih persentase keracunan pada hujan yang terjadi $0,1,2,3$, dan 4 JSA adalah $0,24,25,3$, dan $12 \%$ secara berurut. 
Peningkatan bobot kering gulma daun lebar terjadi ketika adanya hujan setelah aplikasi herbisida glifosat. Hal ini terjadi karena herbisida yang menempel pada permukaan daun telah tercuci. Semakin lama waktu turun hujan setelah aplikasi akan menghasilkan bobot kering gulma daun lebar yang semakin rendah (Tabel 1). Penambahan surfaktan dalam aplikasi herbisida glifosat menyebabkan bobot kering gulma daun lebar lebih rendah dibandingkan dengan aplikasi tanpa penambahan surfaktan (Tabel 1).

Persentase kerusakan gulma daun lebar yang diaplikasikan herbisida glifosat tanpa diikuti hujan setelah aplikasi akan lebih tinggi dibandingkan dengan aplikasi yang diikuti hujan setelah aplikasi. Selain itu, penambahan surfaktan pada aplikasi herbisida glifosat akan menghasilkan persentase kerusakan yang lebih tinggi dibandingkan dengan aplikasi tanpa penambahan surfaktan.

\section{Daya kendali herbisida glifosat pada} gulma teki. Gulma teki yang digunakan sebagai gulma uji adalah Cyperus rotundus dan Cyperus kyllingia.Pengamatan 15 HSA menunjukkan bahwa hujan dapat menurunkan persentase keracunan gulma teki sebesar $22-46 \%$ pada aplikasi tanpa penambahan surfaktan dan 17-35\% pada aplikasi dengan penambahan surfaktan (Gambar 5). Hal tersebut sesuai dengan pernyataan Moenandir (1990) bahwa hujan dapat mencuci herbisida yang menempel pada tumbuhan yang akan menghilangkan efek dari herbisida yang diaplikasikan.

Aplikasi herbisida glifosat dengan penambahan surfaktan menyebabkan gulma teki memiliki persentase keracunan yang lebih tinggi dibandingkan dengan aplikasi tanpa penambahan surfaktan, dengan selisih persentase keracunan pada hujan yang terjadi $0,1,2$, 3 , dan 4 JSA adalah $11,1,2,1$, dan 3\% secara berurutan. Penambahan surfaktan pada aplikasi herbisida glifosat tidak perlu dilakukan apabila akan terjadi hujan 1-4 JSA terlihat dari rendahnya selisih persentase keracunan yang diperoleh jika dibandingkan tanpa surfaktan.

Hujan yang terjadi pada 0-4 JSA dapat menurunkan persentase keracunan gulma teki akibatnya terjadi peningkatan bobot kering. Semakin

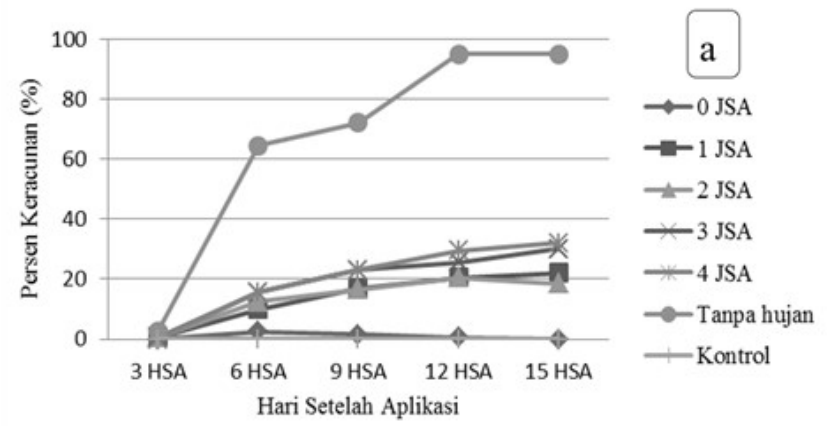

Keterangan :

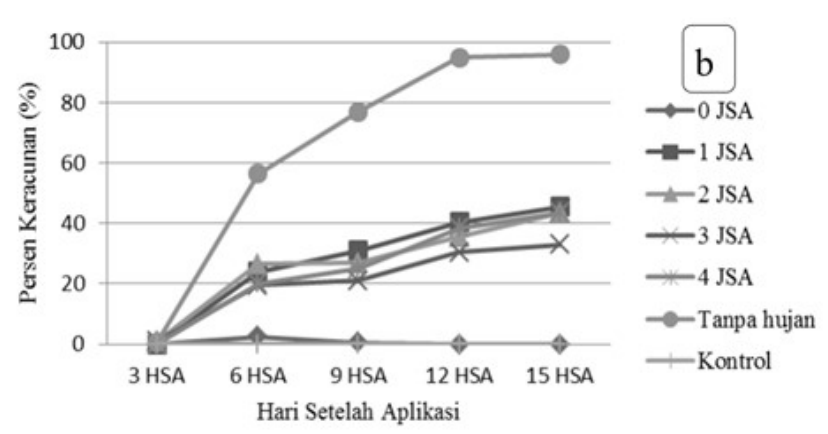

JSA = Jam Setelah Aplikasi $;$ HSA = Hari Setelah Aplikasi

Gambar 4. Persentase keracunan gulma daun lebar: a) tanpa penambahan surfaktan; b) penambahan surfaktan 

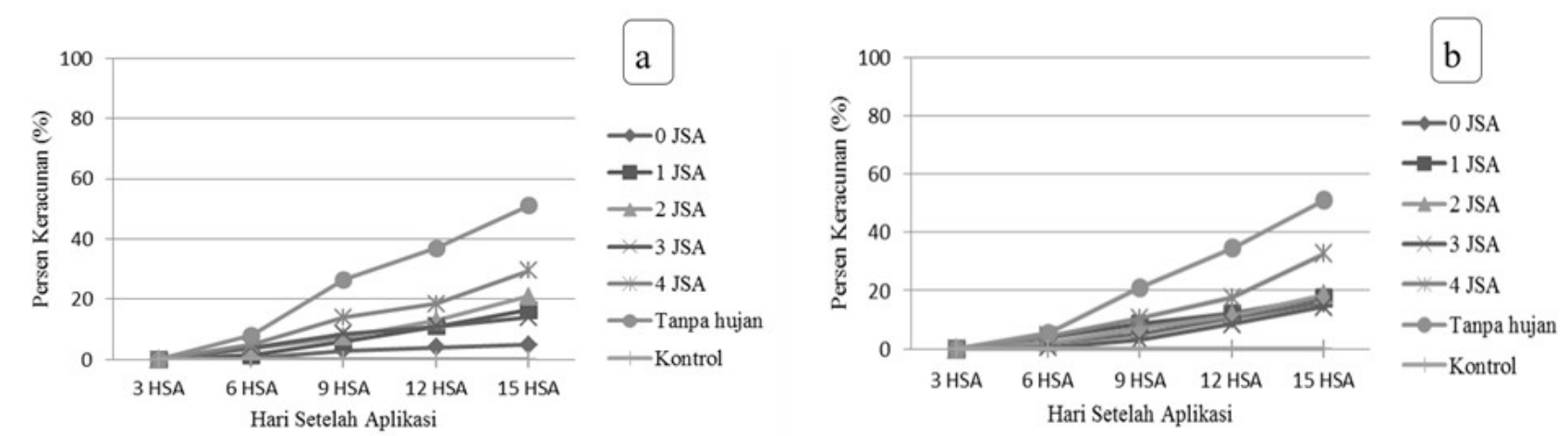

Keterangan :

$\mathrm{JSA}=$ Jam Setelah Aplikasi $;$ HSA $=$ Hari Setelah Aplikasi

Gambar 5. Persentase keracunan gulma teki: a) tanpa penambahan surfaktan, b) penambahan surfaktan

lama waktu terjadinya hujan setelah aplikasi maka bobot kering gulma teki akan semakin rendah (Tabel 1).

Persentase kerusakan gulma teki dipengaruhi oleh adanya hujan tetapi tidak dipengaruhi oleh penambahan surfaktan. Hujan dapat menurunkan tingkat kerusakan pada gulma teki. Semakin cepat hujan yang terjadi setelah aplikasi maka akan semakin rendah persentase kerusakannya.

\section{KESIMPULAN}

Dari hasil penelitian dapat disimpulkan bahwa (1) Surfaktan dapat meningkatkan daya kendali herbisida glifosat pada gulma total, gulma rumput, gulma daun lebar, dan gulma teki dengan peningkatan persentase keracunan secara berurutan mencapai 19, 33, 25, dan $11 \%$ dan memiliki bobot kering yang lebih rendah dibandingkan dengan aplikasi herbisida tanpa surfaktan. (2) Hujan yang terjadi segera setelah aplikasi dapat menurunkan daya kendali herbisida glifosat pada gulma total, gulma rumput, gulma daun lebar, dan gulma teki dengan perununan persentase keracunan secara berurutan mencapai $79,96,96$, dan $46 \%$, sedangkan hujan yang terjadi 4 JSA dapat menurunkan persentase keracunan lebih rendah sebesar 32, 26, 51, dan 18\% secara berurut pada gulma total, gulma rumput, gulma daun lebar, dan gulma teki, dan memiliki bobot kering yang lebih tinggi dibandingkan dengan aplikasi tanpa diikuti hujan setelah aplikasi. (3) Daya kendali herbisida glifosat dengan penambahan surfaktan lebih tinggi dibandingkan dengan tanpa penambahan surfaktan, sedangkan waktu turun hujan 1-4 jam setelah aplikasi dapat menurunkan daya kendali herbisida glifosat.

\section{DAFTAR PUSTAKA}

Anderson, W. P. 1982. Weed Science Principles. WestPublishing.United States ofAmerica. 598hlm.

Cobb, A. H., dan J. P. H. Reade. 2010. Herbicides and Plant Physiology. Wiley Blackwell. United Kingdom. $296 \mathrm{hlm}$.

Gitsopoulus, T. K. I., C. A. Damalas, dan I. Georgoulas. 2014. Improving diquat efficacy on grasses by adding adjuvants to the spray 
solution before use. Planta Daninha 32(2): 355-360.

Girsang, W. 2005. Pengaruh tingkat dosis herbisida isopropilamina glifosat dan selang waktu terjadinya pencucian setelah aplikasi terhadap efektivitas pengendalian gulma pada perkebunan karet (Havea brasiliensis) TBM. Jurnal Penelitian Bidang Ilmu Pertanian 3(2): 31-36.

Hall, L. 2014. How Herbicides Work: Biology to Application. Government of Alberta. Canada. $134 \mathrm{hlm}$.

Hunsche, M., H. Scherhag, M. Schmitz-Eberger dan G Noga. 2007. Influence of rain intensity and rapeseed oil ethoxylate adjuvants on biological efficacy of glyphosate. Journal of Plant Diseases and Protection 114 (4): 176-182.

Miller, P., dan P. Westra. 1998. Herbicide Surfactants and Adjuvants. Colorado State University. Colorado. $3 \mathrm{hlm}$.

Moenandir, J. 1990. Fisiologi Herbisida (Ilmu Gulma : Buku II). Rajawali Press. Jakarta. $143 \mathrm{hlm}$.

Redaksi SI. 2018. KAO Adjuvant, Tingkatan Efektivitas dan Efisiensi Perstisida Kendalikan Gulma. https://sawitindonesia .com/kao-adjuvant-tingkatkanefektivitas-dan-efisiensi-pestisidakendalikan-gulma. Diakses pada 01 Juli 2019 pukul 22.00 WIB.

Riechers, D.E., L.D. Wax, R. A. Liebl, dan D. G. Bullock. 1995. Surfactant Effects on Glyphosate Efficacy. J. Weed Technologi 9 (2) $: 281-285$.

Sembodo, D. R. J. 2010. Gulma dan Pengelolaannya. Graha Ilmu. Yogyakarta. 166 hlm.

Shiddieq, D., P. Sudira, dan Tohari. 2018. Aspek Dasar Agronomi Berkelanjutan. Gadjah Mada University Press. Yogyakarta. $400 \mathrm{hlm}$.

Singh, M., S. D. Sharma dan S. Singh. 2009. Effect of adjuvant and their concentration on rainfall of glyphosate. Indian J. Weed Sci. 41 (3 \& 4) : 199-206.

Sulistyono, E., A. P. Lontoh, dan H. widagdo. 1999. Studi efektivitas pencampuran surfaktan dengan herbisida untuk jalur tanaman karet belum menghasilkan. Bul. Agron. 27(1): 25-29.

Tampubolon, K., Y. S. Sulastri, I. Hamzani, M. Vika, dan Debora. 2017. Kontribusi Curah Hujan dan Hari Hujan terhadap Produksi Tanaman Pangan di Sumatera Utara. Jurnal Teknologi (2) : 65-80 